\title{
Boko Haram and the Geopolitics of Forced Migration in Nigeria
}

\author{
${ }^{1}$ Sadiq Mukhtar, ${ }^{2}$ Rosniza Aznie Che Rose, ${ }^{3}$ Lam Kuok Choy \& ${ }^{4}$ Amina Ummulkhair \\ Ibrahim Bibi-Farouk \\ ${ }^{1}$ Faculty of Earth \& Environmental Sciences, Bayero University Kano, State, Nigeria \\ ${ }^{1,2,3}$ Faculty of Social Sciences and Humanities, Universiti Kebangsaan Malaysia, \\ Malaysia \\ ${ }^{4}$ National Commissions for Refugees, Migrants \& Internally Displaced Persons, Nigeria \\ ${ }^{1}$ Corresponding author: smukhtar.geog@buk.edu.ng \\ DOI: https://doi.org/10.32890/jis2018.14.4 \\ Received: 13 August 2018 \\ Revised: 31 October 2018 \\ Accepted: 12 December 2018
}

\begin{abstract}
Migration is currently perceived as an epitome of globalization and a measuring gauge of global geopolitical mobility. In recent years, Nigeria has been faced with a series of migratory crises such as insurgency and conflict, forcing large numbers of people to flee from their various residential origins to neighboring countries as refugees and asylum seekers or within their country as Internally Displaced Persons (IDPs). This study explores how geographical and political factors intersects to provide explanations on the types and causes of forced migration due to the Boko Haram insurgent activities in Nigeria. The research engages the use of content analysis to examine relevant secondary data on Boko Haram insurgent activities and the geopolitics of forced migration in Nigeria. It is reported that from the total number of 2.1 million forced migrants in Nigeria as of May 2017, 9.7\% are refugees in neighboring countries while others are spatially distributed in different states around the country as internally displaced persons. Furthermore, it was revealed that more than $97 \%$ of the internally displaced persons migrated due to the Boko Haram insurgent activities from the northeastern part of the country. It concluded that the migratory crises in Nigeria is predominantly caused by the activities of the Boko Haram insurgent group that subsequently forced the people to flee their origin because of fear for their lives coupled with the risk of persecution and the destruction of properties.
\end{abstract}

Keywords: Boko Haram, Forced migration, Geopolitics, Migration, Nigeria.

\section{Introduction}

Migration is the movement of people from one spatial geographical location to another and is a global phenomenon affecting the decisions of millions of individuals and families (“Commentary: Migration - A Global Phenomenon," 1994). Palát (2011) deduced that 
migration is an extraordinary phenomenon worldwide and the decision to migrate varies between individuals. Likewise, Amrevurayire and Ojeh (2016) reaffirms that individuals migrate according to prevailing conditions for reasons that varies from one individual to another. Similarly, Ottoh and Akinboye, (2016) suggested that individuals decision to migrate from one place to another is usually due to economic reasons or to flee from oppression, persecution and brutal rules at their origin.

Migration is categorized into different types and dimensions, both internationally and internal, which are voluntary and forced migration. The different types are driven by various factors such as economic, social, political, environmental, developmental and religious, or a combination of any of the two or three of the following factors. At the start of the $21^{\text {st }}$ century, migration has become a topic of interest among academic researchers and policy makers, due to the extensive global increase in the number of both economic and forced migrants (Castles, 2003). Consequently, research on migration studies have been growing rapidly in recent years (Lopez-Carr et al. 2017).

Forced migration, forced displacement or forced immigration is an involuntary coerced movement of people from their habitual residential place of origin to a new destination due to undeniable violence in their place of origin. According to the International Association for the Study of Forced Migration (IASFM), forced migration "is generally a term that refers to the movement of refugees or internally displaced persons (those displaced by conflicts) as well as people displaced by natural and environmental disasters, famine or developmental project" ("What is Forced Migration? - Forced Migration Online," 2012). The International Organization for Migration (IOM) defines forced migrant "as a person who migrate to escape persecution, conflict, repression, natural or human-made disaster, ecological degradation or other situation that endangers his/her quality of life, freedom or livelihood" ("International Organization for Migration (IOM)," 2011; Wickramasekera, 2004). Amrevurayire and Ojeh (2016) also suggested that individuals tend to migrate in order to escape violence, political instability, insecurity and persecution. Therefore, forced migration encompasses population movement caused by conflicts, war, displacement, resettlement and evacuation due to developmental projects or disaster.

Recently, there has been an increase in the occurrences of geopolitical phenomena worldwide (Jabareen, 2015). Additionally, an increase in the number of geopolitical studies have been conducted by scholars to understand and explain the relationship between geography and politics and, space and power (Harker, 2011). The studies of such an issue have been gaining momentum due to the political instability and violent activities that has caused global havoc, disruption of public order and migration.

At the end of Second World War, the world was faced with a series of forced migration crises that were linked with global political tussle (Nail, 2016). However, Castles (2003) argues that since the beginning of the new millennium, forced migration has become very politicized and has subsequently become a vital issue in both national and international 
discussions. He asserts that forced migration has significantly increased in the context of global political transformation and suggests that forced migration is growing in volume and significance due to rising endemic political savagery and human right infringement. Furthermore, policymakers are proposing to implement policies that allows forced migrants the right to seek refuge in any destination area, region or country. Therefore, it is understandable that forced migrants are an integral part of regional and global economic integration. He further suggests that there is a growing understanding that forced migrants do not easily accumulate and accept the receiving destinations' culture and norms but rather tend to retain their own culture, language, norm, religion and tradition, thereby forming communities within the receiving destination. Moreover, forced migration has become a pivotal concern in both national and global level of government. This study uses content analysis to examine relevant secondary data on geopolitics of forced migration and aims to explore how geographical and political factors intersect in providing explanations on the types of forced migration caused by the Boko Haram insurgent activities in Nigeria.

In migration studies, the geographical forces of space, time and distance are of crucial importance. According to Milivinti (2018), migration is a space and time dependent phenomena. Particularly, space is significant as it is involved twice; at the origin and the destination, while time represents the period or year of the movement and the duration of stay. On the other hand, the role of distance in migration studies by Iqbal (2007) adduced that distance is largely recognized as an important factor in forced migration flow, unfortunately, only few studies have been conducted to understand the influences of geographical distance towards forced migration movement.

In relation to the political forces of forced migration, violence and conflict are considered to be the main determinant and the subsequent cause of forced migration. According to Moore and Shellman (2004, 2006, 2007), indigenous and dissident violence at the origin and other political forces have an adverse effect on forced migration flow. Similarly, Huyck and Bouvier (1983) have stated that forced migrants flee from an indefensible violent location to an area that is believed to be safe either within or across international borders. Put differently, forced migrants flee and escape from war, violence, conflict and insurgent activities in their origins by migrating to new destinations that they believe to be safe, secure and free from the forces that had caused the need to migrate.

\section{Methodology}

This study adopts the exploratory research techniques that relies on secondarily available documents and data on Boko Haram insurgent activities. Specifically, the study utilized content analysis approach in analyzing the collected data, narrowed down to the geopolitics of forced migration caused by the activities of Boko Haram insurgent group. The research begins with an introduction to migration and forced migration in section one. Section two explains the methodology utilized for the research. Section three describes the forced 
migration crises in Nigeria. Section four focuses on the history and emergence of Boko Haram insurgent group in Nigeria. Section five lists the historical dates of Boko Haram insurgent activities from 2009 to 2016. Section six explains the types of forced migration caused by the activities of Boko Haram insurgent group. Finally, section seven concludes the major findings of the research.

\section{Forced Migration Crises in Nigeria}

According to Mukhtar et al. (2018), many forces and factors have resulted in the substantial number of the involuntarily forced migratory movement in Nigeria, resulting in displacement of many individuals either as refugees or Internal Displaced Persons (IDPs). Hitherto, Nigeria has experienced many crises such as the Biafra War (1967 - 1970); Mai-Tatsine crises (1979 - 1980); Ijaw unrest (1998 - 1999); Nigeria-Cameroun Bakasi peninsula conflicts; 2011 post-election crises; conflicts in the Niger Delta oil rich region (1990 to date); Southern Kaduna crises in Kaduna state; Jos Plateau crises in Plateau state; Fulani nomadic herdsmen and farmers conflicts; series of inter communal undocumented conflicts and vendetta; as well as the current Boko Haram insurgent activities in Nigeria, Cameroun and Niger Republic (2007 to date). In addition to conflicts and war, Nigeria has also been plagued by numerous natural environmental disasters (Eweka \& Olusegun, 2016; Osagie, 'Funmilayo, Fred, \& Samuel, 2010).

\section{Historical Emergence of Boko Haram Insurgent Group in Nigeria}

According to Onah (2015), the Boko Haram crises is the most recent religious-enthused political violence in the northern part of Nigeria. The Boko Haram crises has led to destruction, havoc and disorder in Africa's most populous country, Nigeria. From assassinations, abductions, bombings and other insurgent activities in the northeastern part of the country, many people have migrated or fled their places of residence to a new location, essentially becoming internally displaced persons, refugees and asylum seekers.

Boko Haram, a term from the Hausa language, a major Nigerian language that literally means "Western Education is forbidden" in English, was founded in 2002 with Headquarters in Maiduguri, the Borno State capital in the northeastern region of Nigeria. The Boko Haram started its first insurgent activity in 2009. However, some researchers have suggested a possible earlier origin in 1995 by its founder, Lawan Abubakar who surfaced from a preexisting group known as the 'Sahaba' (Aliyu, Moorthy, \& Bin Idris, 2015; Harker, 2011; Yerima \& Singh, 2017). When Abubakar left the country for advanced studies in Saudi Arabia, the group was later led by Muhammad Yusuf, who was viewed by many as the pioneer leader of the Boko Haram (Babatunde, Unwana-Obong, \& Olanrewaju, 2014). There are others that have traced the group's origin to Shehu Sani, a right extremist in Northern Nigeria (Abimbola \& Adesole, 2012; Adibe, 2012; Bumah \& Abimbola, 2009; Daryibo, 2009; Langmang, 2011; Uzodike \& Maiangwa, 2012). 
The name of the group has been contentiously debated. However, the group is formally known by its members as "Jama'at Ahlis-sunnah Lid-da 'awati wal Jihad", an Arabic term which means; 'people committed to the propagation of the Prophet's teachings and Jihad'. Other names that the group has been known for, includes; Ahlussunnah wal jama'ah hijra, Yusufiyyah sect, Nigerian Taliban, Movement of Yusuf, Al sunnah wal jama'ah, Afganistan member and most popular Boko Haram (Adibe, 2012; Elden, 2014; Uzodike \& Maiangwa, 2012).

Since 2009, the Boko Haram has engaged in sporadic shootings, bombings, and murders with disdain and impunity in major towns and cities that has killed many people from all walks of life regardless of age, religion, social status and places of residence. In 2013, the United State labeled the group as terrorists after reports that suggested it may have developed into a global terrorist organization with links to al-Qaeda and the Islamic State of Iraq and Syria (ISIS) (Bumah \& Abimbola, 2009; Katie \& Tim, 2015; Langmang, 2011; Yerima \& Singh, 2017).

Since the start of its insurgent activities in 2009, the group has become a serious security threat to the country and has cause the displacement of about 2.3 million people from their homes, making them either internally displaced, refugees or asylum seekers. The threat posed by the organization has killed more than 20,000 people in Nigeria. The Global Terrorist Index of 2015, had ranked them as the most deadliest terrorist group at the time (Institute of Economics and Peace, 2015; Katie \& Tim, 2015).

\section{Historical Dates of Boko Haram Activities 2009 - 2016}

As the insurgent activities in 2009 began to gain momentum, the Boko Haram launched a series of catastrophic terrorist attacks in strategic locations around Nigeria, killing hundreds of people and forcing thousands to flee from these locations (Babatunde et al., 2014; Barau, 2017; John, 2018; Lenshie \& Henry, 2016). Some of the major transgressions that has caused havoc and subsequently forced migration are highlighted:

1. July 2009: The first insurgent attack by the group that led to the killing of 1,000 people that comprised of military and police officers in Maiduguri, the Borno State capital.

2. September 2010: Five people were killed in an attack at Bauchi Central Prison in Bauchi state.

3. December 2010: The first bomb explosion by the group that killed four people outside an army barrack in Abuja, the Federal Capital Territory of Nigeria.

4. May 2011: 15 people were killed after multiple bomb explosions in Abuja and Bauchi state.

5. June 2011: Nigerian Police Headquarters in Abuja was bombed, killing two police officers and injuring many. This is the first suicide bombing by the group. 
6. August 2011: United Nations headquarters in Abuja was bombed, killing 21 people.

7. November 2011: The group killed around 100 to 150 people in Damaturu, Yobe state capital.

8. December 2011: The group killed 68 people in Borno and Yobe state capital. 41 people were also killed by a bomb attack together with the shooting of Christians who were observing prayers at St. Theresa Catholic Church Madalla, Niger State.

9. January 2012: 32 Christians were targeted and killed in a church, and 183 people were killed in Kano state after a series of gun shootings and bombing.

10. April 2012: A church in Kaduna state was attacked, killing 38 people.

11. June 2012: Boko Haram attacked three churches and 19 people were reported dead from the attacks.

12. August 2012: The group launched an attack on Deeper Life Church in Kogi State, killing 19 people. Another attack, aimed at a Mosque killed three people.

13. December 2012: Nearly 43 people were killed in Musari Village, Potiskum and Maiduguri.

14. January 2013: 13 military officers were killed after an ambush by the Boko Haram group.

15. February 2013: Nine women were killed in Kano State.

16. March 2013: A bus bombing led to the killing of 87 people in Kano state.

17. April 2013: 187 people were killed in Baga, the local government of Borno State.

18. June 2013: Boko Haram killed 9 children in Maiduguri State, 13 students in Damaturu, Yobe state and two adults in Ondo state.

19. July 2013: 42 people were killed in Yobe state.

20. August 2013: Nearly 56 people were killed in an attack at a mosque in Maiduguri, Borno state capital.

21. September 2013: Series of multiple attacks in different parts of the country killing more than 250 people.

22. October 2013: 247 people were killed in Borno and Yobe states.

23. January 2014: 163 people were killed in Borno and Yobe state.

24. February 2014: 397 people were killed in multiple attacks and bomb explosions in Borno and Yobe states.

25. March 2014: Boko Haram attacked a military barrack in Borno state and about 600 people were killed during the military skirmish.

26. April 2014: 88 people were killed in Abuja, in a twin bombing attack; 276 Chibok schoolgirls were abducted in Borno state.

27. May 2014: 522 people were killed in multiple attacks in Abuja, Borno, Plateau and Yobe states.

28. June 2014: Around 592 people were killed in Adamawa, Borno, Bauchi and Middle Belt of Nigeria; The group also abducted 91 women and children in Borno state.

29. July 2014: There was an attack that almost destroyed the towns of Damboa and Chibok in Borno state, however, around 69 people were reported to have died from the attack while the other occupants fled. 
30. September 2014: 30 people were killed in an attack in Mainok market in Borno state.

31. October 2014: Five people were killed, 32 injured and 13 vehicles destroyed in an explosion in Gombe state.

32. November 2014: 160 people were killed in Borno and Yobe state; 120 Muslim were also killed on a Friday in a suicide bombing and shooting in the central Juma'at Mosque in Kano State.

33. January 2015: Boko Haram killed about 2000 peoples in multiple attacks in Adamawa, Borno, Bauchi, Taraba and Yobe State.

34. February 2015: Boko Haram launched a series of suicide bombings in Adamawa, Kano, Gombe and Borno State; The group captured and took control of Gwoza local government in Borno state.

35. March 2015: The group killed about 58 people at the polling unit during Nigeria's general election in Gombe state.

36. April 2015: The group captured the town of Marte in Borno state.

37. June 2015: In Borno state, a suicide bombing in Maiduguri Mosque occurred, killing 30 people.

38. July 2015: 44 people were killed in two bomb attacks in Jos, Plateau state.

39. November 2015: 32 people were killed and 80 were wounded in an attack in Yola Adamawa state.

40. January 2016: Around 86 people were killed and hundreds more injured in an attack in Dalori village of Borno state.

41. February 2016: Two suicide bombers sneaked and detonated themselves in Dikwa Internally Displaced Persons (IDP) camps, killing 60 people while injuring 78 others.

42. March 2016: 22 people were killed and 18 others were injured in Umarari Village in Borno state by three suicide bombers; Four people were killed in Askira Uba local government area of Borno state.

43. April 2016: 30 people were killed in a raid in Alau village, Borno state.

44. August 2016: The group burnt 60 houses, shot four people and abducted 20 females.

45. October 2016: Boko Haram killed 31 people in two suicide bombings and series of attacks.

46. December 2016: Three people were killed in two suicide bombings in Borno state.

\section{Forced Migration Caused by Boko Haram Activities in Nigeria}

Forced migrants, including legal and political migrants, are people who are compelled to leave their habitual place of residential origin and seek refuge in a new location. Castles (2003) observes that many popular commentaries tend to incorporate all forced migrants as 'refugees'. However, this notion seems to be intolerant to the fact that a significant number of uprooted individuals are forced to migrate, but remain within their own country of origin. This paper proceeds with a discussion on how the Boko Haram insurgent activities have caused different types of forced migration in Nigeria. 


\section{Refugee}

According to the United Nation High Commission for Refugees (UNHCR 2005), a refugee is "a person who has been forced to flee his or her country of origin because of persecution, conflicts, war, or violence and has a well-founded fear of persecution for reasons of race, religion, nationality, political opinion or membership of a particular social group and is unable or unwilling to return home because he is afraid to do so." In 1951, 140 countries signed the United Nations Convention Relating to the Status of Refugees. Member states agreed to provide protection to people that are persecuted in their countries, and subsequently allow for the consensus of granting these refugees temporary or permanent residency.

The total number of refugees around the world grew from 2.4 million in 1975 to 10.5 million in 1985 and had further increased to 14.9 million in 1990 and later to 18.2 million in 1993 (Castles, 2003, 2005). In 2015, the UNHCR reported that there are about 21.3 million refugees around the world as a result of conflict, war and insecurity. The five countries in the world with the highest number of refugees are; Syria (4.9 million), Afghanistan (2.7 million), Lake Chad Basin (Nigeria, Chad and Cameron) (2.2 million), South Sudan (1.1 million), and Somalia (1 million) (Huber, 2017). The high number of refugees that originated from Nigeria can be traced back to the activities of the Boko Haram insurgent group.

\section{Asylum Seekers}

These are the people who left their countries as political refugees and crossed international borders in search of protection, but their claims for refugee status by the receiving country has not been accepted. In 2014, there were approximately 1.8 million people around the world waiting for a decision on their asylum status (UNHCR, 2015). However, since the start of the Boko Haram insurgent activities in Nigeria, Nigerians have been seeking asylum in different countries around the world, making it difficult to document the number of asylum seekers. Furthermore, the Cameroonian government has denied 100,000 asylum seekers from Nigeria, who declare that their migration is due to fear for their lives as a consequence of the Boko Haram insurgent activities (News Agency of Nigeria (NAN), 2017).

Carling (2005) noted that there is a significant number of Nigerians applying for refugee status in the European countries, and as of 2004, were the fifth largest group of asylum seekers in the world. These refugees expressed the ethnic and religious conflicts that persisted from the Boko Haram insurgency, as their main reason for asylum. However, they were often denied asylum in the European countries as there are many other states within Nigeria and neighbouring West Africa and African countries to migrate to and stay when faced with persecution at their initial residential origin. 


\section{Internally Displaced Persons}

According to the Internal Displacement Monitoring Centre (IDMC), internally displaced people (IDPs) "are persons or groups of people who have been forced or obliged to flee or to leave their homes or places of habitual residence, as a result of or in order to avoid the effects of armed conflict, situations or generalized violence through the violations of human rights or natural or human-made disasters, and who have not crossed an internationally recognized state border" (Internal Displacement Monitoring Centre (IDMC), 2012). It is estimated that the total number of IDPs' around the world rose from 1.2 million in 1982 to 14 million in 1986 and over 20 million in 1997 (Cohen \& Deng, 1998). IDPs' are often referred to as internal forced migrants.

According to the 2015 estimates conducted by the Internal Displacement Monitoring Centre (IDMC), there are approximately 38 million people who are internally forced to migrate and about half of these people are from Africa. The data indicates that almost 15 million people were forced to be internally displaced in Africa. From the 24 countries with the highest number of internally displaced person in the world, nine are African countries (Crisp, 2010). The IDMC global trend on internal displacement in 2014 reported twice the number of internally forced migrants to refugees worldwide, while $60 \%$ of new displacements between 2010 and 2017 occurred in five countries; Iraq, South Sudan, Democratic Republic of Congo (DRC), Syria and Nigeria, whereby Nigeria accounted for almost 8.88\% (IDMC, 2015).

Although internal forced migration is not a new phenomenon in Nigeria, it was only after the emergence of the Boko Haram insurgent group that the country had recorded a large number of IDPs concentrated in refugee camps and host communities. IDMC (2017) deduced that the increasing number of internal forced migrants in Nigeria in recent years is alarming, as there are still an increasing number of people who are forced to leave their homes because of the political reasons caused by the Boko Haram activities (Mukhtar et al., 2018).

\section{Conclusion}

Violence, insecurity and discriminating attacks in Nigeria has forced millions of people to flee their habitual residential of origin to neighboring areas for safety. The number of forced migrants in Nigeria has reached approximately 2.1 million at the end of May 2017. Among these, 1.88 million people that accounts to 90.3 percent, were internally displaced, and the remaining 202,551 (9.7 percent) were refugees in neighboring countries of Cameroon, Chad and Niger Republic (UNHCR, 2017). The UNHCR (2017) reported that out of the 1.88 million internal forced migrants in Nigeria, 1.83 million people were forced to migrate from their habitual place of residential origin due to the increased Boko Haram insurgent activities. Some scholars have linked the migrations to geopolitics of migration and mobility. Doreen Massey (1993) as cited in (Allen et al., 2017) discussed the idea of the politics of migration and argued that different people have different reasons for migration and reaffirms 
that "Some are more in charge of it than others; some initiate flows and movement, others don't; some are of the receiving end of it than others; some are effectively imprisoned by it." Massey further affirms that when migration occurs due to political situation and it is sometimes not an act of individual choice. Creswell (2006) as cited in (Allen et al., 2017) stated that "Migration is rarely just a movement; it carries with it the burden of meaning and it is this meaning that jumps to scale". Moreover, Hyndman (2012) expressed that migration is a constraint and has been a barometer of geopolitics, from displacements generated by conflicts and war to repressive practices in territories and camps.

Geopolitics of forced migration is still in its infancy within scholarship, however, the questions that embodies political, economic and social issues of forced migration are still being critically analyzed by scholars (Allen et al., 2017). The abrupt increase in the number of forced migrants in Nigeria can be linked to the activities of the terrorist group, Boko Haram. Boko Haram has generated large numbers of forced migrants in Nigeria, as people migrated due to the insecurities caused by the group. Millions of people were forced to flee areas that were once safe and secured. In conclusion, forced migration caused by conflicts, war and insurgency are identified as the root cause for geopolitical mobility in Nigeria.

\section{Acknowledgement}

The authors gratefully acknowledge the support of the UKM research grant (EP-2017-049, EP-2017-034) and the Ministry of Science and Technology (MOSTI) grant (FRGS/1/2016/ SS07/UKM/03/1).

\section{References}

Abimbola, J. ., \& Adesole, S. A. (2012). Domestic terrorism and Boko Haram insurgency in Nigeria issues and trend: A historical discourse. Journal of Arts and Contemporary Society, 4, 12-29.

Adibe, J. (2012). Boko Haram: One sect, conflicting narratives. African Renaissance, 9(9), 27-36.

Aliyu, A., Moorthy, R., \& Bin Idris, N. A. (2015). Towards understanding the Boko Haram phenomenon in Nigeria. Asian Social Science, 11(10), 307-317. https://doi. org/10.5539/ass.v11n10p307

Allen, W., Anderson, B., Van Hear, N., Sumption, M., Düvell, F., Hough, J., ... Walker, S. (2017). Who Counts in Crises? The new geopolitics of international migration and refugee governance. Geopolitics, O0(00), 1-27. https://doi.org/10.1080/14650045.20 17.1327740

Amrevurayire, E. O., \& Ojeh, V. N. (2016). Consequences of rural-urban migration on the source region of Ughievwen clan Delta State Nigeria. European Journal of Geography, 7(3), 42-57. 
Babatunde, M. M., Unwana-Obong, U. D., \& Olanrewaju, M. K. (2014). Historical antecedents of Boko Haram insurgency and its implications for sustainable and educational development in North Central Nigeria. Journal of Education and Practice, 5(22), 59-66.

Barau, A. (2017). Women and children fleeing Boko Haram: Their experiences in Nigerian cities. Nigeria: IIED. Retrieved from http://pubs.iied.org/17429IIED

Bumah, J., \& Abimbola, A. (2009). The Boko Haram tragedy and other issues. The Punch.

Carling, J. (2005). Gender dimensions of international migration. Global Migration Perspectives. Retrieved from http://www.prio.no/sptrans/-259065811/file46701_ gmp_no_35.pdf

Castles, S. (2003). The international politics of forced migration. Development, 46(3), 1120. https://doi.org/10.1177/10116370030463003

Castles, S. (2005). Global perspectives on forced migration. Asian And Pacific Migration Journal, 15(December 2004), 1-18.

Cohen, R., \& Deng, F. M. (1998). Masses in flight: The global crisis of internal displacement. Washington DC.

Commentary: Migration - A global phenomenon. (1994). Peace Research, 26(4), 73-76. Retrieved from http://www.jstor.org/stable/23607258

Crisp, J. (2010). Forced displacement in Africa: Dimensions, difficulties, and policy directions. Refugee Survey Quarterly, 29(3), 1-27. https://doi.org/10.1093/rsq/ hdq031

Daryibo, N. D. (2009). Islamic fundamentalism and sectarican violence: The maitatsine and Boko Haram crisis in northern Nigeria. (Peace and Conflict Studies Paper Series). Ibadan.

Elden, S. (2014). The geopolitics of Boko Haram and Nigeria's "War on Terror." Geographical Journal, 180(4), 414-425. https://doi.org/10.1111/geoj.12120

Eweka, O., \& Olusegun, T. O. (2016). Management of internally displaced persons in Africa: Comparing Nigeria and Cameroon. An International Multidisciplinary Journal, 10(40), 193-210. https://doi.org/10.4314/afrrev.v10i1.15

Harker, C. (2011). Geopolitics and family in Palestine. Geoforum, 42(3), 306-315. https:// doi.org/10.1016/j.geoforum.2010.06.007

Huber, C. (2017). Forced to flee: Top 5 countries refugees are coming from. Retrieved January 2, 2018, from https://www.worldvision.org/refugees-news-stories/forcedflee-top-5-countries-refugees

Huyck, E. E., \& Bouvier, L. F. (1983). The demography of refugees. The Annals of American Academy of Political and Social Science, 467, 39-61.

Hyndman, J. (2012). The geopolitics of migration and mobility. Geopolitics, 17(2), 243255. https://doi.org/10.1080/14650045.2011.569321

Institute of Economics and Peace. (2015). Global Terrorism Index 2015. Retrieved from economicandpeace.org/wp-content/uploads/2015/11/Global-Terrorism-Index-2015. pdf 
Internal Displacement Monitoring Centre (IDMC). (2012). Internal displacement in Africa: A Development challenge exploring development initiatives to alleviate internal displacement caused by conflict, violence and natural disaster.

Internal Displacement Monitoring Centre (IDMC). (2015). Global overview 2015, people internally displaced by conflict and violence. Retrieved from http://www.internaldisplacement.org/assets/library/Media/201505-Global-Overview-2015/20150506global-overview-2015-en.pdf

International Organization for Migration (IOM). (2011). Retrieved December 25, 2017, from https://web.archive.org/web/20111010050241/http://www.iom.int/jahia/Jahia/ about-migration/key-migration-terms/lang/en\#Forced-migration

Iqbal, Z. (2007). The Geo-Politics of Forced Migration in Africa, 1992-2001. Conflict Management and Peace Science, 24 (November), 105-119. https://doi. org/10.1080/07388940701257515

Jabareen, Y. (2015). The emerging Islamic state: Terror, territoriality, and the agenda of social transformation. Geoforum, 58, 51-55. https://doi.org/10.1016/j. geoforum.2014.10.009

John, T. (2018, February). Boko Haram Has kidnapped dozens of schoolgirls, again. Here's what to know. Time Magazine. Retrieved from http://time.com/5175464/bokoharam-kidnap-dapchi-schoolgirls/

Katie, P., \& Tim, H. (2015). Boko Haram overtakes ISIS as wolrd's deadliest terror group Report Says. Retrieved from edition.cnn.com/2015/11/17/world/global-terror-report/ Langmang, J. (2011). The upsurge of religion fundamentalism: A critical reflection in the light of the Boko Haram phenomenon in northern Nigeria. In G. . Best (Ed.), Religion and post conflict peace building in northern Nigeria. Ibadan: John Archers Publishers Ltd.

Lenshie, E. N., \& Henry, Y. B. (2016). Boko Haram insurgency, internally displaced persons and humanitarian response in northeast Nigeria. The International Journal of Humanities \& Social Studies, 4(August), 141-150.

Lopez-Carr, D., Martinez, A., Bilsborrow, R. E., \& Whitmore, T. M. (2017). Geographical and individual determinants of rural out-migration to a tropical forest protected area: The Maya biosphere reserve, Guatemala. European Journal of Geography, 8(2), 78-106. Retrieved from https://www.scopus.com/inward/record.uri?eid=2-s2.085020669977\&partnerID=40\&md5=fc670676c0d66bc345546681af08a7ac

Milivinti, A. (2018). A spatio-temporal analysis of migration. Empirical Economics, Retrieved from https://doi.org/10.1007/s00181-018-1514-8

Moore, W. H., \& Shellman, S. M. (2006). Refugee or internally displaced persons? To where should one flee? Comparative Political Studies, 39(5), 599-622.

Moore, W. H., \& Shellman, S. M. (2007). Whither will they go? A global study of refugees' destinations, 1965-1995. International Studies Quarterly, 51, 811-834.

Moore, W., \& Shellman, S. (2004). Fear of Persecution. Journal of Conflict Resolution, 48(5), 723-745.

Mukhtar, S., Rosniza Aznie, C. R., Lam, K. C., Mokhtar, J., Aiyub, K., \& Toriman, M. E. (2018). Spatio-temporal analysis of internal forced migration in northeastern 
Nigeria spatio-temporal analysis of internal forced migration in northeastern Nigeria. International Journal of Academic Research in Business and Social Sciences, 8(13, Special Issue: Community Development \& Social Mobility), 76-84. https://doi. org/10.6007/IJARBSS/v8-i13/4811

Nail, T. (2016). A tale of two crises: Migration and terrorism after the Paris attacks. Studies in Ethnicity and Nationalism, 16(1), 158-167. Retrieved from http://du.academia. edu/thomasnail.

News Agency of Nigeria (NAN). (2017, September 27). Cameroon deports 100,000 Nigerian asylum seekers. SaharaReporters. Retrieved from http://saharareporters. com/2017/09/27/cameroon-deports-100000-nigerian-asylum-seekers

Onah, E. I. (2015). Boko Haram insurgency and the 2015 general elections in Nigeria. Journal of International Studies, 11, 15-28.

Osagie, J., 'Funmilayo, A., Fred, A., \& Samuel, E. (2010). Causes of conflicts in the Niger delta region of Nigeria as expressed by the youth in Delta state. Procedia Social and Behavioral Sciences, 5(Supplement C), 82-89. https://doi.org/https://doi. org/10.1016/j.sbspro.2010.07.055

Ottoh, F. O., \& Akinboye, S. O. (2016). It Is not yet 'Uhuru': Overcoming the challenges of citizenship and nationality questions in post-separation Sudan and South Sudan. Journal of International Studies, 12, 81-94.

Palát, M. (2011). Economic causes and consequences of international migration of labour. Discussions on Estonian Economic Policy, 121-137. Retrieved from http://papers. ssrn.com/sol3/papers.cfm?abstract_id=1998852

UNHCR. (2017). Nigeria situation UNHCR regional update. Retrieved from https:// reliefweb.int/sites/reliefweb.int/files/resources/UNHCR Regional Update - Nigeria Situation - May 2017.pdf

Uzodike, U., \& Maiangwa, B. (2012). Boko Haram terrorism in Nigeria: Causal factors and central problematic. African Renaissance, 9(1), 41-49.

What is Forced Migration? - Forced migration online. (2012). Retrieved from http://www. forcedmigration.org/about/whatisfm/what-is-forced-migration

Wickramasekera, P. (2004). Asian labour migration: Issues and challenges in an era of globalization. Geneva.

Yerima, H. M., \& Singh, R. D. S. (2017). Insurgency in Nigeria: The perspectives on health care delivery to gender affected victims amongst IDPs. IOSR Journal of Humanities and Social Science, 22(05), 35-41. https://doi.org/10.9790/0837-2205033541 